\title{
Cannes 2006
}

\author{
By Ron Holloway
}

Fall 2006 Issue of KINEMA

\section{FEATURE REPORT: GILLES JACOB LOOKS TO THE FUTURE}

The $59^{\text {th }}$ Festival de Cannes (17-28 May 2006) was already preparing for its $60^{\text {th }}$ birthday party in 2007. That's the impression I got during an all-embracing and far-ranging conversation with Gilles Jacob, festival President and close observer of ongoing events on the Côte d'Azur since 1964, back when he covered the scene as a French journalist from Paris. When I asked him where he housed all the guests and participants at this year's festival, he replied bluntly: "We don't!" Adding with a smile: "To fit everyone under the skirt of Cannes during the festival, we would require 10,000 more rooms. That means four times more than what we already have!" Yet, instead of musing over the possibility of reducing the size of the Cannes festival in the future, Gilles Jacob talked about expanding its scope even further. "Right now, we need another screening facility with circa 800 seats." Then, without me asking why, he added: "We have so many films to show. There's no other option. I've already talked to the government here in Cannes."

That's also when the festival president warmed to his favourite theme and underscored in his quiet way the reasons why Cannes is the greatest film showcase on the face of the earth. "Just look at the record," he stated with a smile. "Anyone can see what's happened here over the years." Glancing back over my own shoulder, I noted how he took a two-competition-films-a-day-festival (with a day off for a picnic in the woods) and retooled it into a dozen showcases of quality world cinema. How over nearly three decades as délégué général he had engineered the growth of a dozen innovations. How he molded a closely knit team into a smooth running organization to oversee thousands of productions annually around the globe. At the core of team are Thierry Frémaux (délégué artistique), Christian Jeune (documentation), Christine Aimé (press), the Jacob sons Laurent and Didier, to name just the key people he personally confides in.

Cannes is a labyrinth that few can really navigate well. Ask even veteran journalists to name the sections, and they tend to get lost even with the official program in their hands. No one even has the time to visit them all: Un Certain Regard, Courts Métrages, Cinéfondation, Cannes Classics, Tous les Cinémas du Monde, L'Atélier du Festival (to support projects by young talent), Les Leçons (this year's lessons: actress Gena Rowlands, film composers Alexandre Desplat and Jacques Audiard, director Sydney Pollack), Exposition (Sergei Eisenstein's erotic drawings), Cinéma de la Plage (Beach Projections), and La Journée de l'Europe (European Day for Cultural Ministers). All these, in addition to a gigantic Marché du Film with its village of white show tents stretching down the Croisette.

When I asked Gilles Jacob about his dream project - the construction of a Cannes Film Museum and whether it would be ready for the $60^{\text {th }}$ anniversary festival - he countered with a glint in his eye: "It all depends on the architects. First, the money has to be raised. Then, of course, the project has to be opened to a competition - we want the best architect to design the museum. Only after all that can we start with the building itself." If all goes well, enthused Jacob, "the Cannes Film Museum will be an all-year-around attraction on the Côte d'Azur."

\section{Preview of Cannes Attractions}

The guessing game for the competition entries at the 59th Festival de Cannes was unofficially launched in mid February, when Thierry Frémaux, the artistic director, paid an unexpected visit to the Berlinale and went on record with an offside comment to inquiring journalists. "Last year, you saw a classic line-up of festival entries," he said. "This year, you can expect some surprises." A week later, when I phoned Frémaux at his Paris office as to what sort of "surprises" might be in the making, he countered with a heartfelt opinion that "balance is very important" - meaning that the art of the cinema can be found just about anywhere in the world today. For that matter, "balance" in the official program is the same rule of thumb followed over the past three decades by Gilles Jacob, formerly the festival's artistic director and now its president. So we are back to square one and had to wait until April 20, when the official Cannes press conference was scheduled. 
At that time, the only absolutely certain entry in the official program was the opening night slot reserved for Ron Howard's The Da Vinci Code, starring Tom Hanks and Audrey Tautou. As much a Parisian event as it was a Hollywood thriller based on Dan Brown's best-seller, The Da Vinci Code is set partially in the Louvre and stars the same Audrey Tautou of Amélie of Montmartre, one of biggest box office hits in contemporary French cinema. Further, the American release of The Da Vinci Code had been purposely held back until after the Cannes gala screening on the hunch that the film would surely benefit from the festival brouhaha. This, and the publicity generated by the recent translation of a discovered apocryphal text, the Gnostic Gospel of Judas. Why? Because Gnosticism of the third century is one of the red threads running through both the book and the film, although its presence helped little to unravel the mysteries of the Da Vinci Code. In fact, Cannes critics were never so unanimous in voting the film a flop. No matter. Reports have it that the film grossed $\$ 77$ million over the first weekend in the United States and Canada alone. That, too, must be a Cannes record. American producers will be swarming to get another blockbuster into the $60^{\text {th }}$ Festival de Cannes in 2007.

\section{Love Paris - $20 \times 5$}

Adding to the Francophile flavour of the festival, it was decided early on that the Un Certain Regard section would open with an omnibus collection titled Paris, je t'aime - a so-called "love anthology" with 20 episodes of five minutes each set in all of the city's 20 districts. The potpourri was co-directed by 20 diverse auteurs, among them Joel and Ethan Coen, Gus Van Sant, Alexander Payne, Wes Craven, Walter Salles, Olivier Assayas, Gérard Depardieu, Gurinder Chadha, and Tom Tykwer. The producers of Paris, I Love You are none other than Claudie Ossard and Emmanuel Benbihy, who brought Amélie to the screen. Apparently, the idea was to duplicate the red carpet festivities of opening night by laying out a blue carpet on the steps leading up to the Salle Debussy when the Un Certain Regard section opened on the night after The Da Vinci Code. Of course, the list of stars who showed for the Paris, je t'aime gala - among them, Juliette Binoche and Fanny Ardant - was enough to choke traffic halfway down the Croisette. Narrating a love story in just five minutes is quite a trick, to say the least. The best episode struck pay-dirt on the comic side. In Joel and Ethan Coen's Tuileries the setting is the Tuileries metro station in the 1st arrondissement, with Steve Buscemi (a Coen regular) as the wet-eared American in Paris.

\section{Visit to Versailles}

Seldom have Cannes veterans been so right in predicting in advance the core of the Cannes competition. New films by Sofia Coppola, Pedro Almodóvar, Nuri Bilge Ceylan, Nanni Moretti, Aki Kaurismäki, Alejandro Gonzalez Iñárritu, and Ken Loach were on practically everyone's list. Of course, it was not difficult to imagine that Sofia Coppola's Marie-Antoinette would indeed bypass Venice to premiere at Cannes instead. Shot on location at Versailles, Marie-Antoinette was a natural for Cannes window-dressing. A stylized story of the Austrian teenaged queen and her dull-witted consort, Louis XVI, it stars Kirsten Dunst - the same thespian who played 14-year-old Lux in The Virgin Suicides (1999), Sofia Coppola's first feature film. Booed at the press screening, Marie-Antoinette, by all accounts a stunning costume drama, still received a half-dozen à la folie (sheer madness) palms on the Le Français daily voting chart.

The international jury, however, was not impressed: Sofia Coppola went home empty-handed. Perhaps because nothing of any social or political consequence happens in Marie-Antoinette save for the funny, fanatic, fumbling efforts of the coquettish queen to bed the feeble-minded king and eventually produce a dauphin. Come the déluge, the pair apparently don't have a clue as to what is going on around them. MarieAntoinette's historic line, "Let them eat cake," thrown in the face of starving peasants, rings as hollow as the film itself. Still, this must be the first instance in film history that Marie-Antoinette is depicted as a naive innocent instead of an uncaring monarch oblivious to the even the evils in her own court. No French director, to my knowledge, has dared to tell her story.

\section{Golden Palm for Ken Loach}

The International Jury was full of surprises. Not that anyone would expect anything else by a jury headed by maverick Chinese-Hong Kong director Wong Kar-wai. His choice as jury president can be considered a surprise as well. The biggest surprise was registered on the face of British director Ken Loach, who had to be flown back to Cannes for the awards night. This being his eighth run for the Palms, he honestly stated that he didn't expect to win, particularly since The Wind That Shakes the Barley was positioned at the front of the festival on the very first day of the competition. "All I can say is that the film is not just about the 
conflict between brothers during the Irish rebellion," Loach said in an interview. "It's also about the war in Iraq." Maybe so, but his comparison between Ireland in 1920 and Iraq in 2005 does seem a bit far fetched. Indeed, the film's political and social relevance can be found elsewhere. The fact that The Wind That Shakes the Barley is a British director's view of Black and Tan brutality in a Ireland seeking its independence and about to lose its way in a bloody civil war, that makes for engrossing cinema - and reason enough to win the Golden Palm.

Old-timers at Cannes, it should be added, rejoiced at the jury decision. I myself happen to be on hand back in 1970, when Ken Loach's Kes was presented in the Week of the Critics at Cannes to the collective approval by the writing press. That story of a shy boy in the poverty-stricken Midlands whose only friend is a wild falcon, a kestrel he had captured and trained, set the tone for a new realism in British cinema. Two years ago, at the $57^{\text {th }}$ Cannes festival, Ken Loach was awarded an honorary citation by Interfilm, the Protestant side of the Ecumenical Jury, for his long-time service on behalf of the disadvantaged and the downtrodden.

\section{Fate of a Favourite}

At the awards gala television cameras caught disappointment written all over the face of Spanish director Pedro Almodóvar. Positioned towards the front of the competition, Almodóvar's Volver (Return) was one of the frontrunners from the start. The story of an apparently deceased mother returning to set matters straight with her two daughters and granddaughter, this warm comedy on the melodramatic side was applauded for 20 minutes at the premiere and brought tears to the eyes of actress Penelope Cruz. Pedro Almodóvar, awarded the Palm for Best Screenplay, voiced an eternal truth when he said after the awards ceremony that "to be the odds-on favourite at the beginning of the festival is bad luck - this is the second time it's happened to me," He was referring to the defeat suffered in 1999, when his Todo sobre mi madre (All About My Mother) was hailed by critics as one of the highlights of the season.

Now, on the second time around, and after opening the 2004 Cannes festival with the personal La mala educación (Bad Education), Pedro Almodóvar visibly ached to finally win the Golden Palm. Instead, he had to be satisfied with a runner-up screenplay citation, while Penélope Cruz and the femme leads in Return collectively received the Palm for Best Actress. Why all six actresses in Volver should be equally honoured with a Palm, particularly since Penélope Cruz alone merited the standing ovation at the premiere, might be attributed to a moment of fleeting largesse on the part of some jury members. But when that same virus attacked again, and all five actors in Rachid Bouchareb's Indigènes (Days of Glory, France-Morocco-Belgium) were collectively awarded the Palm for Best Actor, then acting performances at this year's Cannes festival appeared to have been decided by a roll of the dice.

\section{War Stories}

Rachid Bouchareb's Indigènes (Days of Glory - aka Native Born, France-Morocco-Algeria-Belgium), for the most part a plodding war film, was nevertheless regarded as a long overdue salute to Arab soldiers from Algeria and Morocco who had fought in the French army for the liberation of France in the Second World War without receiving just recognition. Scenes of contempt for black soldiers by French army superiors add to the poignancy of the film. One might say that this is a French answer to Steven Spielberg's Saving Private Ryan (1998), for the theme in general is sacrifice and pride in a job well done. In an interview Bouchareb himself took pride in noting that his own grandfather had fought on the side of the French during the First World War.

Bruno Dumont's Flandres (France), awarded the runner-up Grand Prix, tells a numbing tale of war atrocities inflicted on the African population by lads from poverty-stricken Flanders. Recruited by the French Foreign Legion, they are simply sent off to war. Since neither a time nor a place are readily defined, Flandres comes across as a metaphoric statement on the senseless logic on modern-day warfare, in which raw recruits on a patrol can readily lose their humanity and resort to rape and pillage. The scene might just as well be Iraq as the desert of North Africa.

\section{Political Statements}

Based on a true story, Israel Adrián Caetano's Crónica de un fuga (Chronicle of an Escape, Argentina) is the first Argentine film about the country's so-called "dirty war" (1976-83). Only recently are the facts known about the disappearance of an estimated 30,000 citizens, who were rounded up, imprisoned, tortured, and killed by "task groups" commissioned by the Argentine military government. Often, the arrests were just 
arbitrary choices, as in the case of the soccer goalkeeper Claudio Tamburrini (Rodrigo de la Sema), kidnapped in Buenos Aires in 1977. Together with three other prisoners, Claudio survives mental and physical torture until their escape is made possible during a thunderstorm.

Although Lou Ye's Summer Palace (China-France) - a Chinese title was not listed in the Cannes catalogue - covers Chinese history from 1987 to 2001, the key sequence focuses on the Beijing student uprising on Tiananmen Square in May of 1989 (a event, by the way, that was followed closely on TV by Cannes participants). To Lou Ye's credit, this is the first time that the Tiananmen Square incident has appeared in a Chinese film, albeit as background footage and narrative material. The primary theme of Summer Palace, set mostly in the dormitories of Beijing University, is sexual freedom with political confrontation with the authorities thrown in on the side. In fact, there is so much open sex in the film that Lou Ye confirmed in an interview that he plans to cut the film considerably to meet current Chinese censorship standards. Whether the film's political message will survive the cuts is another question.

\section{Auteur Cinema}

Some Italian critics felt that Nanni Moretti's Il Caimano (The Caiman, Italy-France), a light comedy about Italian Media Mogul cum Prime Minister Silvio Berlusconi, had been inspired by Michael Moore's Fahrenheit 9/11 (USA), the Bush-basher that bagged the Golden Palm in 2004. Released in Italy just before the elections, Il Caimano did well at the box office and seem to profit even from Berlusconi's subsequent showdown with Romano Prodi over a "stolen election.". At Cannes, however, the film hardly caused a ripple. Conceived as a film-within-a-film, the title referring to an anti-Berlusconi screenplay handed to a reluctant but needy producer, The Caiman only catches fire when on-camera TV footage of the bumbling prime minister hit the screen to enliven a plodding narrative.

Finland's cult director Aki Kaurismäki, whose international reputation rises with each passing festival, presented the third film in his trilogy on the plight of the working man in Helsinki. The series was launched in Cannes a decade ago when Kauas pilvet karkaavat (Drifting Clouds, 1996), a statement on the unemployed, was awarded at Cannes (Kati Outinen, a Kaurismäki regular, was awarded the Palm for Best Actress). Then, in 2002, Cannes invited his Mies vailla menneisyyttä (The Man Without a Past), a poignant tale about the homeless as experienced by an amnesia victim. Now, in Laitakaupungin Valot (Lights in the Dusk), a story of betrayal and loneliness, the film ends on a pessimistic note of sacrifice - and ultimately despair that the innocent will always be exploited by the powers that be. Aki's familiar ensemble faces are missing from Lights in the Dusk, which may be the reason that the film drew mild applause at the press screening.

Another closing film in an auteur trilogy was eagerly awaited at Cannes. Babel, a biting tale of noncommunication set in three continents, is Alejandro Gonzáles Iñárritu's third (and apparently last) collaboration with talented screenwriter Guillermo Arriaga, who also collaborated at last year's Cannes festival with American actor-director Tommy Lee Jones on awarded Three Burials of Melquiades Estrada (2005). The writer-director pair's good fortune began at Cannes six years ago when their Amores Perros (Love's a Bitch, Mexico, 2000), a multi-layered tale constructed around a street accident, took the Week of the Critics by storm. It was followed by the equally praised 21 Grams (USA, 2003), an interwoven story of love and guilt forged around a transplanted heart. In Babel children play a key role in this overlapping and over-stretched chronicle of stumbling word-play misunderstandings between cultures that leaves inevitably to tragedy. Why in the first place the American pair, played by Brad Pitt and Cate Blanchett, are on a tourist bus somewhere in the Moroccan desert is never really explained. And the time gaps in the film, too, don't seem to interlock the way they should over the two-hours-plus narrative line. Still, Alejandro Gonzáles Iñárritu well deserved the Palm for Best Director. He also received the Ecumenical Award.

Another front runner for Cannes laurels was Turkish director Nuri Bilge Ceylan's Iklimler (Climates). As the title hints, Climates is shot in intersecting episodes against the changing seasons of blistering summer, rainy autumn, and frosty winter. Only spring is missing, although Bahar - Turkish for "spring" - just happens to be the name of the female protagonist. The plodding, excruciating tale of a relationship slowly falling apart confirms that Nuri Bilge Ceylan is one of the most thought-provoking directors working in cinema today. An acclaimed master at probing the loneliness of the soul, Ceylan blends powerful imagery with sparse dialogue in this personal tales of a lost chance and a fatal decision. Climates stars Nuri Bilge Ceylan himself as the university professor Isa (Turkish for "Jesus"), his wife Ebru Ceylan as his loving but wounded girlfriend 
Bahar. Ceylan has often been compared with Bergman, Bresson, Antonioni, and Tarkovsky. However, when I interviewed him last year at the Cinefan festival in New Delhi about his Uzak (Distant), awarded the runner-up Grand Prix at the 2003 Cannes festival, he only wanted to talk about the cinema of Andrei Tarkovsky.

Unfortunately, Nuri Bilge Ceylan's Climates was completely overlooked by the international jury at Cannes. But it did receive the FIPRESCI (International Critics) Award. It deserved the Golden Palm.

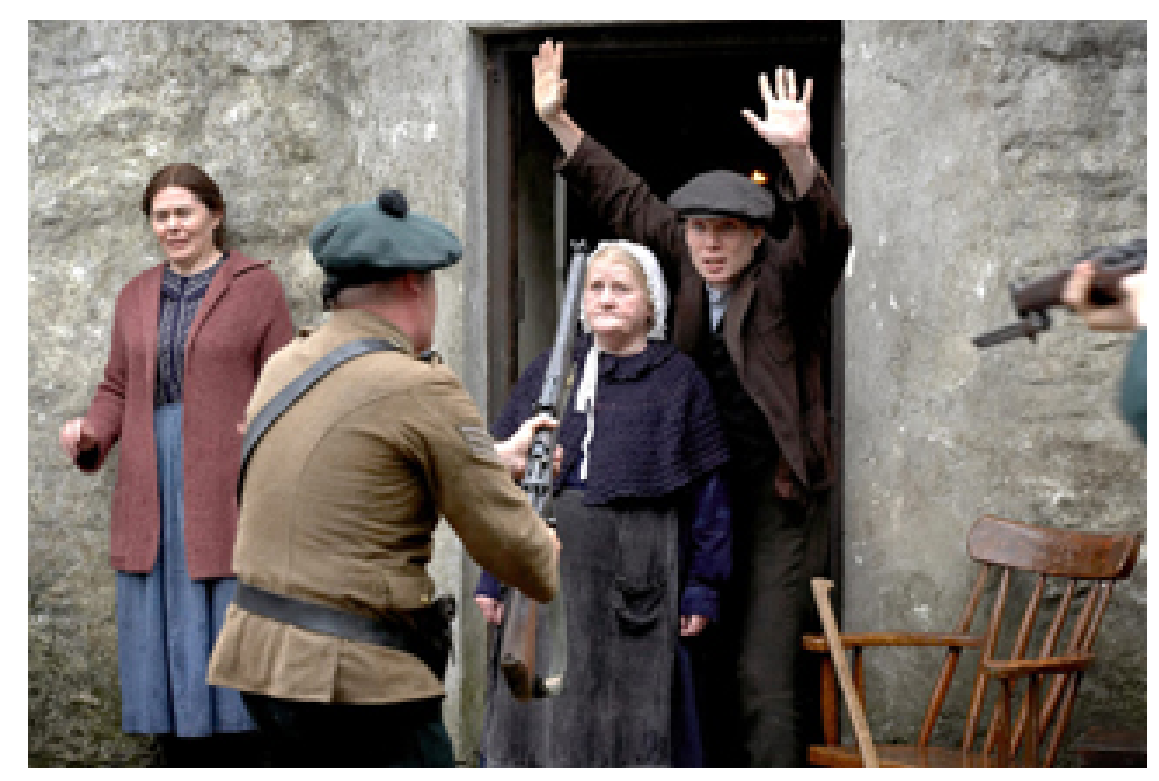

Figure 1: 2006 Golden Palm Winner: The Wind that Shakes the Barley by Ken Loach

\section{CANNES SIDEBARS 2006}

Flying home from Cannes on the same plane with German director Volker Schlöndorff, who had paid a short complimentary visit to the Riviera, I queried him for his impressions of the festival under the twin leadership of president Gilles Jacob and artistic director Thierry Frémaux. "If I had known before how strong the Directors Fortnight was, I might have considered entering my new film on the Polish Solidarity movement here instead of waiting for Venice." My response was a bit too facetious for the occasion: "You could have entered Streik! (Strike!) in any section at Cannes and come out a winner!"

In short, this year's Cannes film festival offered the committed cineaste a diverse display of world cinema. Each of the traditional sections - Competition, Un Certain Regard, Directors Fortnight, Week of the Critics - offered enough to keep one busy the entire week. The new sections - Cannes Classics, Midnight Screenings, tous les cinémas du monde - proved to be just as tantalizing. And the Film Market was crowded with journalists who wanted to sneak a preview of Kim Ki-duk's Shi gan (Time, South Korea), the opening night film at the upcoming Karlovy Vary film festival. Indeed, the Cannes palette was rich in novelties and discoveries.

\section{Frank Otto's Trip}

Was it a presentation in the Film Market? Or a Special Event organized by Berlin-based entrepreneur Jürgen Schau? Whatever. Only a pesky, whipping, blowing mistral wind-storm prevented Frank Otto's Trip from becoming the event of the Cannes showcase. As it was, some 500 guests showed at the indoor Majestic Barrière beach site to submerge themselves into an audiovisual experience conceived by Hamburg media artists Frank Otto and Bernt Koehler-Adams. Programmed as an experimental assemblage of music and film, the "trip" at Cannes was more on the musical side, although an overall team of musicians, artists, designers, and filmmakers were initially involved. If the presentation had taken place at the end of Majestic pier - as originally planned, where the show could have been viewed by hundreds up and down the Croisette 
- the Trip would have been the talk of the festival.

Improvisation is at the heart of this multi-media plunge intended to "re-mix your experience." The key premise is to link four separate films running simultaneously on a split-screen to original musical compositions that allow live performers, singers and musicians, to navigate their own way through the overall experience. Each of the four films, plus segments of others, were commissioned productions shot over the past couple years. One film is an eye-catching silent-movie melodrama, another is an underwater sea exploration, a third (track 2) is a fast-moving ride on the Berlin Underground, and the wrap, titled Playing Planet, is a whirlwind trip to Africa, San Francisco, and the Philippines. The unifying element is the soundtrack, which both supports and extends the appeal to the individual as he or she constantly "re-mixes the audiovisual experience" to fit their personal taste. Tripping with Frank Otto has to be seen more than once to grasp the depth of the experience.

\section{Out-of-Competition}

The visit of Al Gore to the Croisette to attend the out-of-competition screening of Davis Guggenheim's $A n$ Inconvenient Truth (USA) caused a stir and some open-ended speculation on whether he might be considering a rerun for the office of President. According to the press book, Al Gore has given his multi-media, spreadsheet, slide-show lecture on global warning over a thousand times at a lecture tour and on his own cable TV channel. Perhaps Davis Guggenheim's documentary is too smooth and generous in his promotion of a "new" Al Gore - humorous, earnest, caring and worried - but the message comes across without a hitch and free of political finesse. If you too were not concerned about unpredictable twisters, rising flood waters, melting glaciers, stifling heat waves, among other increasing natural catastrophes, then your worst fears will be confirmed after seeing An Inconvenient Truth.

Another highlight was the out-of-competition screening of Paul Greengrass's United 93, the emotionally charged recapitulation of what happened and might have happened on the fourth highjacked 9-11 United Airlines flight that ended up crashing into a field instead of the intended White House. To Greengrass's credit, he enlisted commercial airline pilots and flight attendants to play the respective roles, thus adding to the authenticity of the fiction narrative. Computer-simulated plane-bouncing and a hand-held camera (cinematographer Barry Ackroyd) were additional pluses. And on a Sunday afternoon Oliver Stone offered the Cannes public a half-hour sneak-preview of his upcoming World Trade Center epic about the heroism of policemen and firemen to save others in Tower One at the cost of their own lives. The icing on the cake was an introduction by Thierry Frémaux of Oliver Stone's Platoon (USA), a 1986 Cannes hit that Stone at the presentation called "one of the greatest experiences of my life."

Another Hollywood director, Sydney Pollack, presented at Cannes Sketches of Frank Gehry (USA), his first documentary - and made only because the eminent American architect, creator of the Guggenheim Museum in Bilbao and the Walt Disney Concert Hall in Los Angeles, asked him as a friend to do him the favour. As the title hints, the film is a compilation of sketches rather than an analytical approach to the architect's varied career. "Sketches" pretty much describes two other French films in the out-of-competition section. Douglas Gordon and Philippe Parreno's Zidane, un portrait du 21st siècle simply follows the legendary soccer player for Real Madrid across the turf on a single day during a famous match. And in Anne Feinsilber's Requiem for Billy the Kid the focus is mostly a wide-screen homage to Lincoln County's striking landscape, while on the side comparing the persona of Billy the Kid to that of rebellious French poet Arthur Rimbaud. Why on earth this comparison? Because, says Anne Feinsilber, both myth-enshrouded personalities died at 21.

\section{Midnight Screenings}

The midnight screening of gay director John Cameron Mitchell's Shortbus (USA) was billed as an attempt to bring narrative legitimacy to the porn film industry. Shot on a tight budget over 30 days, it features a cast of nonprofessionals who had signed up for Mitchell's multi-sex workshop on the premise that everything should go on this sexual battlefield. As much a sad film as it is a playful libido-tickler, Shortbus (the title refers to regular gay-kitsch soirees in a Manhattan underground club) drew additional free publicity by having most of cast hanging around the Cannes bars throughout the festival. When Mitchell himself was asked what happened to whether professional actors had signed up for his workshop, he admitted that some did, but nearly all of them quickly exited when the chips were down. Not surprising, because Shortbus is quirky porn 
and nothing more. Hardly worth of cult status, as some critics have claimed.

Prolific Hong Kong director Johnnie To was back in town with Election 2 (Hong Kong-China), the sequel to his Election in the Competition at last year's Cannes. A Triad action film about the bloody election of a new chairman, the first edition went on to gross an estimated $\$ 2$ million within weeks after the Cannes premiere. This time around, for Election 2, Johnny To has fattened out the plot and added more psychological depth to the gangster thriller. The rerun reportedly has already grossed $\$ 700,000$ within four days of its release last April. One now expects to see more of Johnny To at future Cannes fests.

\section{Cannes Classics}

Fast becoming one of the major pillars of the festival, Cannes Classics paid posthumous tributes to Carol Reed (1906-1976) and Norman McLaren (1914-1987). Hopefully, the restored prints of Reed's The Way Ahead (1944), Odd Man Out (1947), The Fallen Idol (1948), and A Kid for Two Farthings (1955) will make the rounds of several international film festivals. In my student days I was inspired to study cinema after seeing Odd Man Out a dozen times at the Clark Theater in downtown Chicago. How wonderful to see a restored print of this British classic!

In the section's documentaries on cinema, it was also a distinct pleasure to view Marie Génin's $I l$ était une fois... Rome ville ouverte (Once Upon a Time... Rome, Open City, France) and Sam Pollard's John Ford John Wayne: The Filmmaker and the Legend (USA). The former reviewed the making of Roberto Rossellini's neorealist classic shot under the noses of the Germans during the last days of the occupation. The latter is particularly noteworthy for puncturing the hero bubble of draft-dodger John Wayne while his mentor John Ford was serving in the Navy. In one teasing narrative segment about the making of They Were Expendable (USA, 1945), the story of the defeat of American forces in the Philippines in 1941-42, we hear how Ford forced Wayne to correctly salute a superior officer with the catcall to do it over and over again until he gets it right. Wayne in Ford's eyes was anything but the war hero he portrayed in countless Hollywood films.

\section{Un Certain Regard}

Since 1978, a separate jury has been nominated by the festival to award a key film in this back-up section to the Competition entries. The Main Prize was justly awarded to Wang Chao's Jiang chen xia ri (Luxury Car, China-France), the third film in his trilogy on the "dark side of Chinese society" that began with The Orphan of Anyang (2001) and continued with Day and Night (2004). The story of an elderly school teacher who returns to Wuhan in central China after 40 years to find his long-lost son, the journey in Luxury Car is triggered by the wish of his ill wife to see her son once more before she dies of cancer. Upon arriving in the city, he first pays a visit to his pregnant daughter and tries to repair that relationship too as best he can, although he knows that her job as an escort is along the same lines as the hooker she shares an apartment with. The old man is finally helped in his search by a retired cop, who suffers the same pain of a missing son. Luxury Car confirms Wang Chao, whose roots are found in the working class, as one of China's leading auteur directors.

Just as impressive was Rolf de Heer's Ten Canoes (Australia), an aboriginal tale set in the forbidding Arafura Swamp in northern Australia that's infested with crocodiles. The photography alone of this tropical swamp-and-bush country was enough to guarantee a Special Jury Prize. Ten Canoes is a mythical, ancestral tale told in flashback, as though the contemporary story of a young man who covets his brother's third wife is as old as the indigenous tribe itself. By contrast, Garin Nugroho's Serambi (the direct translation is Veranda, or a meeting place for family and friends) documents the aftermath of the tsunami tragedy that hit the Indonesian province of Aceh on 26 December 2004 and cost the lives of more than 200,000 inhabitants. Aided by three other directors and four cameramen, Serambi chronicles the lives of survivors without resorting to sentimental pathos. Indeed, some sequences are profoundly poetic.

Paz Encina's Hamaca Paraguaya (Paraguayan Hammock, Paraguay-Argentina-Netherlands-France-Spain) is the first 35mm, all-Paraguayan feature film since the 1970s. Commissioned by theatre director Peter Sellars for the New Crowned Hope Festival and the Vienna Mozart Year 2006, its general theme is keeping hope alive in spite of all. The setting is Paraguay during the Chaco War of 1932-35 between Paraguay and Bolivia. Two old people are waiting on their small farm for some news from their soldier son, even though their meandering conversation hints that he may no longer be alive. Nothing else happens to enliven the static long takes in which they sit on a hammock and quarrel to pass the time away. Still, this first feature by a 
promising young femme talent showed enough class to merit a FIPRESCI International Critics award.

Two films from Eastern Europe drew strong critical praise as well. In Catalin Mitulescu's debut feature Cum mi-am petrecut sfarsitul lumii (The Way I Spent the End of the World, Romania-France) the end of the Ceauescu era in 1989 is viewed through the eyes of Eva (Dorotheea Petre) a 17-year-old girl, whose fatal mistake was accidentally tipping over a bust of the dictator at her school - an offence great enough to get her kicked out and sent to a reformatory. There she plots with a lad from a dissident family to escape to freedom by crossing the Danube, a plan however that unravels before it even takes shape. Dorotheea Petre was awarded Best Actress by the Un Certain Regard jury.

Tajik director Jamshed Usmanov, internationally known for his folksy Flight of the Bee (1998) and Angel on the Right (2002), hit pay-dirt again with Bihist faqat baroi murdagon (To Get to Heaven You First Have to Die, Tajikistan-France). A tongue-in-cheek voyeuristic tale about a lad who can't make love to his young bride, the problem is partially resolved when his sophisticated city cousin decides to help. When the lad finally does hit it off with a married woman at a factory, who should happen along but the irate husband with apparent links to the local mafia. Deadpan humour keeps To Get to Heaven You First Have to Die moving along at a light pace with some neat dips and turns in the plot.

György Palfi's Taxidermia, whose Hukkle (Hiccups, 2002) won him a trip to Sundance, shared top award honours at the Budapest Festival of Hungarian Films last February. Set in three political time periods the Second World War, the Communist dictatorship, and present-day capitalist Hungary - the title refers to the surprising taxidermist finale of a weird grandfather-father-son relationship. Partly horrific, occasionally pornographic, uncomfortably violent, and completely crazy from beginning to end, Taxidermia begs description - indeed, it is as unorthodox as it is perverse.

\section{Directors Fortnight}

Hajdu Szabolcs's Feher tenyer (White Palms, Hungary-Canada), awarded the other half of the Gene Moskowitz Prize at the Budapest Festival of Hungarian Films, is a scrutinizing portrait of training methods for young gymnasts at the Olympics. Drawing on autobiographical experiences and factual material to weigh the pros and cons of subjugating promising teenage athletes to rigorous training methods that leave scars long into adulthood, the film comes alive during the flashbacks to a time when a sensitive lad is terrorized by a sadistic trainer. Even his parents fall under his spell, who only think of the fame of a prodigy showered upon themselves as well. Some years later, after a career-ending accident, the one-time prodigy is training youths in Canada for an international tournament. His methods, at the start, are not much different than those he suffered under in his youth. So, one wonders, what's the point of the film?

Corneliu Porumboiu's written-and-directed A fost sau n-a fost? (12:08 East of Bucharest, aka Did It Happen or Not? in direct translation, Romania) was one of the discoveries of the Cannes festival. It's December 22 in a small Romanian town east of Bucharest, and 16 years have passed since the "revolution" that dispensed with Ceauescu. For the anniversary the head of a local TV station decides to invite two discussion partners to find out where they were during the uprising, and whether or not they had participated in the protests on that early afternoon before the city hall. One is history teacher who drinks too much, the other is a lonely retiree who is planning to play Santa Claus for the neighbourhood kids. The fun begins when pro-and-contra phone calls come pouring in to confuse the memory lesson all the more. A political spoof with unexpected humorous twists, 12:08 East of Bucharest deserves a long festival run.

An angry feature-length cartoon, Anders Morgenthaler's Princess (Denmark), was the talk of the upbeat Directors Fortnight. Reminiscent of Martin Scorsese's Taxi Driver (USA, 1976), the loose gun in this case is a missionary priest who returns home to look after the 5-year-old daughter of her deceased sister, a porn star, known in the profession as "The Princess," who died of drug abuse. Upon realizing that the little girl has already been abused by her foster parents, the ex-monk decides to wreak revenge by destroying all the porn films his sister starred in. He begins by issuing a warning to the Paradise Lost porno company, then resorts to violence when his threats go unheeded. Princess, budgeted at a reported $\$ 1.2$ million, was inspired by Japanese anime productions. On thematic material alone, it deserves a long festival run.

Stefan Krohmer's Sommer '04 an der Schlei (Summer '04, Germany), scripted by Daniel Nocke, reunites the writer-director team that scored with Sie haben Knut (They've Got Knut, 2003), a satire about apolitical 
"revolutionaries" set in the loose-living 1980s at an Austrian ski-lodge. This time, the resort is a sailing paradise on the Schei River in eastern Germany where it empties into the Baltic Sea. The entourage embraces a sexually liberated couple who are joined at their vacation idyll by their 15-year-old son and his 12-year-old Lolita girlfriend. As if that is not enough to make a few marital waves, along comes a young handsome sailing Lothario, who apparently is looking for some tender companionship too. Martina Gedeck, as the distraught 40-year-old mother, gives a fine performance as a woman caught between her errant emotions and her shaken sense of responsibility. The summer vacation ends on a tragic note.

Two thrillers were plugged with advertising largesse in the Directors Fortnight. Bong Joon-ho's The Host (South Korea) is an \$11-million sci-fi thriller about a Loch-Ness-style sea monster that terrorizes the good people of Seoul on the Han River during a torrid summer heat spell. The special effects alone are said to cost $\$ 4.5$ million. Result: a monster half as scary as the Great White Shark and somewhat comical with his whip-around tail. It's the efforts of a half-witted family to defeat "the host" that makes for suspenseful entertainment. By contrast, Bill Friedkin's Bug (USA), a psycho-thriller set in a motel room, explores the limits of paranoia. It begins when a mysterious stranger spots a tiny bug in the lady-friend's bed that may or may not be part of an evil military experiment. Soon the bug is magnified into weird connotations of attacks upon the persona, dragging both parties into a maelstrom of delirium. Bug, marking the return of Hollywood veteran Bill Friedkin to Cannes, was voted a FIPRESCI International Critics Award.

\section{Week of the Critics}

Matthias Luthardt's Pingpong (Germany) drew some warranted attention as one of the two German entries across the board at Cannes. A coming-of-age story, it depicts the pain of an angry 16-year-old after the suicide of his father. Sent to live with relatives in eastern Germany, he feels more isolated than ever. But it is summer, and sexual urges can find an avenue of release when the youngster encounters a mature woman with yens of her own. A give-and-take game of ping-pong with all the members of the family begins.

Agnes Kocsis's Fresh Air (Hungary), awarded last February the Sandor Simo Prize for Best Debut Feature at the Budapest Festival of Hungarian Films, proved to be a hit in the Week of the Critics as well. The story of a fragile relationship between a mother and daughter, their obsessive daily rituals in a crowded but tidy apartment eventually drive both to rebellion although they seldom talk to each other. The mother, who works during the day cleaning subway toilets, is scorned by her daughter for the lavatory odours she brings home with her, simply because the former is forever scrubbing her body while the latter flaunts her desire to become a fashion-designer. What unites them is a mutual liking for an Italian TV crime series. And, in the end, Agnes Kocsis hints that there is no way out of their shared crises except living together and making the best of it.

\section{Tous les cinémas du monde}

Launched last year to accommodate overlooked films from seven national cinematographies, the nod in All the Cinemas of the World this time around went to Russia, Israel, Singapore, Switzerland, Venezuela, Tunisia, and Chile. Cineastes with a yen for Russian cinema could catch Alexei Uchitel's art film Kosmos kak predchuvstvie (Dreaming of Space), awarded at Moscow last year, and Fyodor Bondarchuk's war actioner 9 rota (The Ninth Company), the biggest box office success of the past season.

And if you've never seen a film from Singapore, there was a modest collection of shorts and features on display, including Jack Neo's light comedy I Am Not Stupid Too. At the same time, a prominently located Singapore stand was magnanimously supported by government officials. Why they don't invest in their own internationally recognized Singapore International Film Festival under the enlightened leadership of Philip Cheah and his team, is another question altogether. Are their cultural leaders that afraid of quality festival cinema?

\section{References}

\section{PRIZES AND AWARDS}

\section{Official Competition}

Palme d'Or: The Wind That Shakes the Barley (UK-Ireland-Germany-Italy-Spain), dir Ken Loach. 
Grand Prix: Flandres (France), dir Bruno Dumont

Best Director: Alejandro González Iñárritu, Babel (USA)

Best Screenplay: Pedro Almodovar, Volver (Return, Spain), dir Pedro Almodóvar

Best Actress: Penélope Cruz, Carmen Maura, Lola Dueñas, Blanca Portillo, Yohana Cobo, Chus Lampreave, Volver (Spain), dir Pedro Almodóvar

Best Actor: Jamel Debbouze, Samy Nacéri, Roschdy Zem, Sami Bouajila, Bernard Blancan, Indigènes (Days of Glory - aka Native Born, France-Morocco-Algeria-Belgium), dir Rachid Bouchareb

Jury Prize: Red Road (UK-Denmark), dir Andrea Arnold

Short Film Awards

Palme d'Or: Sniffer (Norway), dir Bobbie Peers

Jury Prize: Primera Nieve (First Snow, France), dir Pablo Aguero

Special Mention: Conte de quartier (Neighbourhood Story, France-Canada), dir Florence Miailhe (animation)

Caméra d'Or - Best Debut Film

A fost sau -a fost? (12:08 East of Bucharest - aka Did It Happen or Not?, Romania), dir Corneliu Porumboiu (Directors Fortnight)

Un Certain Regard Awards

Prix Un Certain Regard - Fondation Gan pour le Cinéma: Luxury Car (China-France), dir Chao Wang

Special Jury Prize: Ten Canoes (Australia), dir Rolf de Heer

Best Actress: Dorotheea Petre, Cum mi-am petrecut sfârsitul lumii (The Way I Spent the End of the World, Romania), dir Catalin Mitulescu

Best Actor: Don Angel Tavira, El violin (The Violin, Mexico), dir Francisco Vargas

Prize of President of Un Certain Regard Jury: Meurtrieres (Murderers, France), dir Patrick Grandperret

\section{Cinéfondation Awards}

First Prize: Ge \& Zeta (Argentina), dir Gustavo Riet

Second Prize: Mr. Schwartz, Mr. Hazen \& Mr. Horlocker (Germany), dir Stefan Mueller

Third Prize: (ex aequo): Mother(USA), dir Siân Heder and A Vírus (The Virus, Hungary), dir Agnes Kocsis

Directors Fortnight

Regard Jeune: Day Night Day Night (USA-Germany-France), dir Julia Loktev

CICAE Art \& Essai Prize: Anche libero va bene (Along the Ridge - aka Even Independent It's All Right, Italy), dir Kim Rossi Stuart

Europa Cinemas Label: A fost sau n-a fost? (12:08 East of Bucharest - aka Did It Happen or Not?, Romania), dir Corneliu Porumboiu (Directors Fortnight)

SACD Award (French Short Film): Dans le rang (In the Rank), Cyprian Vial

Young French Director Award (Short Film): Bosilka Simonovitch, Un Rat (A Rat)

Critics' Week

Grand Prix: Les Amitiés maléfiques (The Malevolent Friendships, France), dir Emmanuel Bourdieu

Prix ACID: Den Brysomme Mannen (The Bothersome Man, Norway), dir Jens Lien

Grand Prix CANAL+ (Short Film): Kristall (Crystal, Germany), dir Christoph Girardet, Matthias Müller

Prix SACD (ex aequo): Pingpong (Germany), dir Matthias Luthardt and Les Amitiés maléfiques (The Malevolent Friendships, France), dir Emmanuel Bourdieu

Prix Grand Cru: Alguma Coisa Assim (Something Like That, Brazil), dir Esmir Filho

Prize Regard Jeune: Sonhos de Peixe (Brazil-Russia-USA), dir Kirill Mikhanovsky

Grand Rail d'Or (Feature Film): Les Amitiés maléfiques (The Malevolent Friendships, France), dir Emmanuel Bourdieu

Petit Rail d'Or (Short Film): Printed Rainbow (India), dir Gitanjali Rao

Prix OFAJ de la (Toute) Jeune Critique (ex aequo): Pingpong (Germany), dir Matthias Luthardt 
and Iron (Japan), dir Hiroyuki Nakano

KODAK Discovery Award (Short Film): Printed Rainbow (India), dir Gitanjali Rao

FIPRESCI (International Critics) Awards

Competition: Iklimler (Climates, Turkey), dir Nuri Bilge Ceylan

Un Certain Regard: Hamaca Paraguaya (Paraquay), dir Paz Encina

Directors Fortnight: Bug (USA), dir William Friedkin

Ecumenical Award

Competition: Babel (USA), dir Alejandro González Iñárritu

Special Mention - Un Certain Regard: Z odzysku (Retrieval, Poland), dir Slawomir Fabicki

\section{Author Information}

Ron HOLLOWAY (1933-2009) was an American critic, film historian, filmmaker and correspondent who adopted Europe as his home in the early fifties and spent much of his life in Berlin. He was an expert on the study of German cinema and against all odds produced, with his wife Dorothea, the journal German Film, keeping us up-to-date with the work of directors, producers and writers and the showing of German films around the world.

In 2007, Ron Holloway and his wife were awarded the Berlinale Camera Award. Ron also received the Bundesverdienstkreuz (German Cross of Merit), Polish Rings, Cannes Gold Medaille, the American Cinema Foundation Award, the Diploma for Support of Russian Cinema and an honorary award from the German Film Critics' Association.

Ron was also a valued contributor to Kinema for the past fifteen years. 